\title{
ARTICLE
}

\section{Engineering and War}

\author{
Dean Nieusma ${ }^{*}$ and Ethan Blue ${ }^{\dagger}$ \\ * Department of Science and Technology Studies, Rensselaer Polytechnic Institute, nieusma@rpi.edu \\ † Department of History, University of Western Australia, ethan.blue@uwa.edu.au
}

This paper shows how the connections between engineering and warfare/militarism are closer than is usually recognized. It investigates the nature of that relationship using theoretical perspectives from critical theory and social constructionism. We draw on historical research into the influence of military institutions and interests on the field of engineering, but also look broadly at cultures of warfare that extend beyond formalized military institutions. Focusing on engineering labor and engineering epistemologies, we suggest that engineering today can be understood as a "war-built" discipline-even when practiced apart from military institutions and projects. We put forward "social justice" as an idealized alternative foundation for engineering. In addition to serving as a corrective to the inordinate influence of militarism on engineering, a social-justice-based approach could also sensitize engineers and others to the pervasive role of social context in shaping both what engineers do and how that is understood to serve broad public interests.

KEYWORDS: militarism, war, history, labor, epistemology

\section{INTRODUCTION}

What does engineering have to do with war? It seems an odd question, perhaps, given that warfare is generally understood as the act of organized destruction, while engineering is (surely among other things) the act of organized creation. In what follows, we will draw on broad traditions in historical analysis and social theory to argue that the connections between engineering and warfare-and engineering and militarism—are closer than is usually recognized.

Probably more than any other "non-military" discipline, militarism and cultures of warfare have shaped engineering; this paper investigates the nature of that shaping. Drawing on historical research and critical theory, we discuss the influence of military institutions and interests on the field of engineering, but also look broadly at cultures of warfare that extend beyond formalized military institutions. Drawing on social constructionism, we highlight how militarist assumptions are internalized into engineering knowledge and practice and then speculate on the possible implications of replacing militarism with social justice as a foundational assumption of engineering.

\section{War-torn and War-built Societies}

To set the stage for our analysis, it may help to consider a loose but suggestive distinction between what we call war-torn and war-built societies. We hear a good deal in the news about war-torn societies, and examples of these abound in history and around the world: from Sri Lanka to Sudan to Nicaragua to Kosovo to Iraq, and even in some pockets of the so-called developed world. The places where the bombs and bullets are expended are war-torn. In those places, and for the people who inhabit them, war is a force of social disaggregation. It destroys lives, families, bodies, and 
social ties. For the people who struggle to survive in the face of destruction, war is a mode of social and cultural entropy, an unstable base on which there is no other choice than to survive-try to live, try to love, try to rebuild.

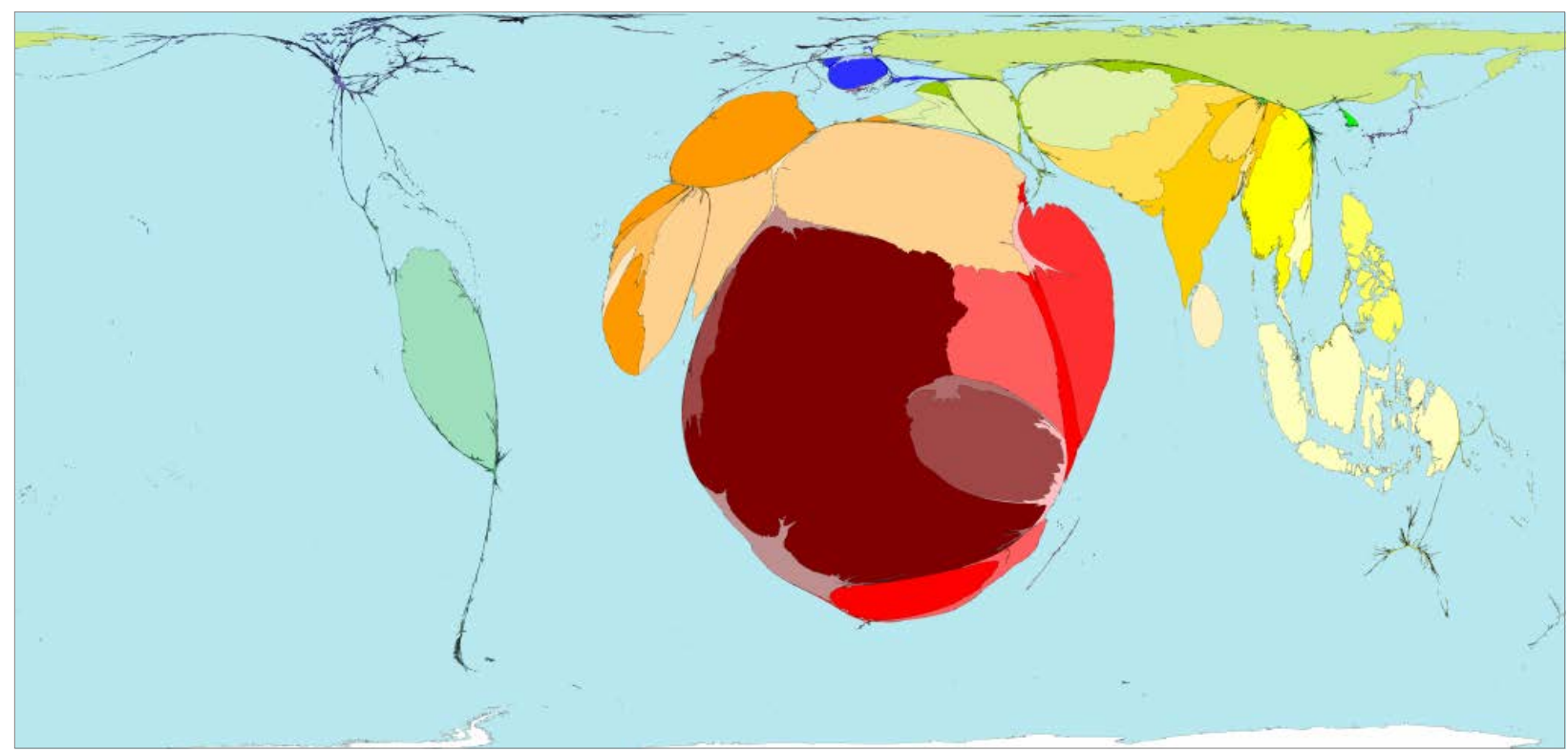

Figure 1: War Deaths, 2002. ${ }^{1}$ Territory size shows the proportion of deaths worldwide directly attributed to war or conflict that happened there.

But for others, war is a boon. The places where bombs are designed and built (and here we mean built in well-appointed factories rather than in basements or attics) might be understood as warbuilt societies. As the world's largest arms exporter, the United States certainly qualifies here, as do a number of other significant arms exporters, including Russia, Germany, France, and the United Kingdom. ${ }^{2}$ Internationally, warfare or the threat of war during the $19^{\text {th }}$ and $20^{\text {th }}$ centuries allowed nations in the global North access to and control over expanded markets across the planet, concentrating resources and profits according to existing colonial and neocolonial relationships. Designers of jet engines, next-generation torpedoes, and predator drones are well remunerated, as are the stockholders in their ventures. So too are the communities whose tax-bases balloon thanks to military spending. Warfare provides a foundation for these societies to build by providing jobs, social meaning, and moral certainty in having enemies against whom one can define oneself.

1 (C) Copyright SASI Group (University of Sheffield) and Mark Newman (University of Michigan). Reproduced with permission under Creative Commons.

2 "The report by Congressional Research Service, an arm of the Library of Congress, showed that American contractors sold nearly $\$ 11.8$ billion in weapons in 1999-more than a third of the world's total and more than all European countries combined" (Myers 2000). More recent 2009 data shows United States exports holding approximately steady (SIPRI 2011), followed by Russia in a distant second, and then (with another large gap) Germany, France, and United Kingdom. 


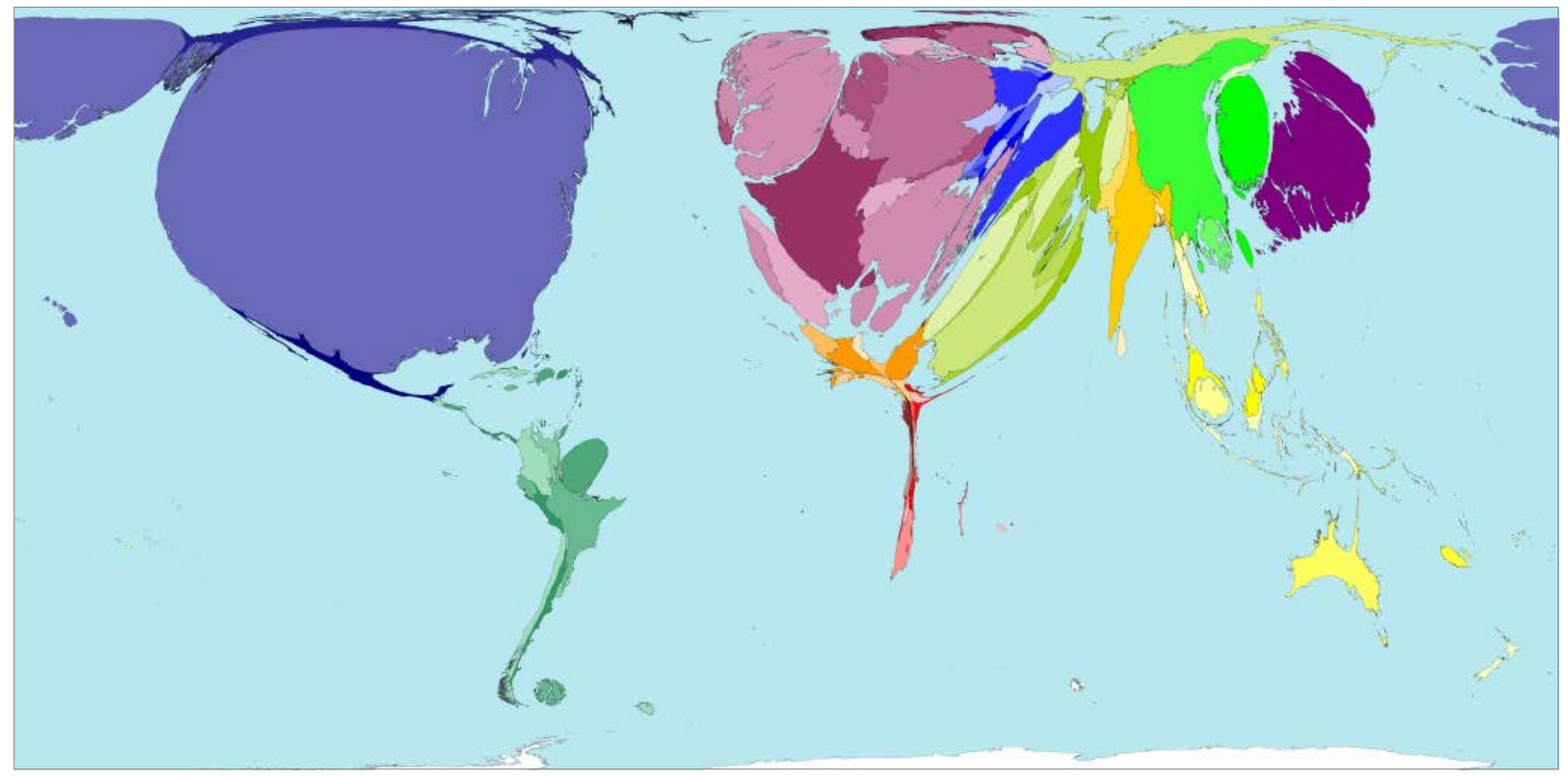

Figure 2: Military Spending, 2002. ${ }^{3}$ Territory size shows the proportion of worldwide state military spending by territory in 2002 .

The United States, for example, has waged numerous wars, both literal and metaphorical. From its inception as a settler colonial society, certainly, but also in its more recent wars on concepts and abstract nouns. Domestically, it has seen wars on crime in the 1930s and again in the 1970s, a war on drugs, a war on poverty, and now a war on terror. Overseas, it has seen wars (or police actions) in the Philippines, Cuba, Haiti, Mexico and throughout Latin America, two wars in Europe, and two more in East Asia. Beginning with World War II and persisting through the Cold War, military spending was the literal foundation of the US economy (Chafe, 2010). Military Keynesianism drove everything from road-building programs to factory openings, sanctioned by a bargain among the federal government, large corporations, and the politically centrist unions that garnered stable, high-wage jobs for their members, thereby ensuring that US-dominated capitalism prevailed over Soviet communism and other economies across the third world. All of this required massive building, massive spending, and massive engineering, which was directed by states and governments, but also by private corporations-and the best work was done when their interests aligned, as in World War II and the Cold War (Lipsitz, 1994).

The benefits of these literal and conceptual wars are not evenly distributed, of course, even for such powers as the United States. Military service has been seen by many subordinated peoples as a path toward social inclusion, a source of income and respect otherwise denied, and a means to make rights-based demands on the polity-demands that have often been violently contested (Du Bois, 1919; Appy, 1993; Alvarez, 2008). Low-ranking soldiers are killed or return traumatized, to be sure, and generals and politicians offer their lamentations, but there is no shortage of ceremonies that can act, however feebly for grieving families, as a palliative. Moreover, in the wars on crime and drugs, the late $20^{\text {th }}$-century builders of American prisons reaped great profits (and private prison operators may continue to do so), while the many millions who pass through those prisonsmostly poor, black, and brown-gain little and lose much. But for those members of subordinate classes who successfully struggle to gain an education, and place themselves in careers that bolster rather than challenge the status quo, they can benefit from newfound privileges. Many hierarchical

3 (C) Copyright SASI Group (University of Sheffield) and Mark Newman (University of Michigan). Reproduced with permission under Creative Commons. 
societies are today supple enough to allow this differential inclusion, from the military to finance, from politics to engineering.

\section{Reimagining a War-built Discipline}

Of course, there are more direct connections between engineering and warfare. Military technologies must be imagined, designed, built, and rebuilt. For their part, engineering historians have long noted the influence of military institutions and cultures of warfare more generally on the field of engineering (Adas, 2006; Roland 1993). This influence is seen in the birth of the term "engineer" as one who operates siege engines-early technologies of warfare-and it extends to present-day institutions and practices within engineering both inside and outside war-related industries.

In addressing the extent to which militarism and cultures of warfare have shaped and continue to shape engineering, this paper seeks to make two points, and these points exist in tension with one another. The first point is that "history matters." However seemingly irrelevant to any particular present requirements of engineering as a discipline, militarism continues to shape-to varying degrees and in various direct and indirect ways-much of what engineers do. In important respects, engineers cannot escape engineering's history. Henry Ford, one of America's great engineers, quipped that "History is bunk"-in other words, that the past is irrelevant, and only the future matters. We disagree-in the deepest terms.

The second point is that, despite history's influence, engineering can be reimagined and reconstructed along different lines. Engineering's history, like all history, entails contingenciessituations and circumstances in which things could have been different. As engineering historian, Peter Meiksins, puts it,

[T] he maintenance of forms of organization is a contingent historical process, involving conflict.... [M]ost occupations will experience recurrent conflict over how they should organize themselves as the different types of practitioners press their various points of view. It is only as an outcome of such conflict that one model is able to predominate. (1986, p. 417)

This insight applies not only to how engineering is organized as an occupation and practiced in various settings, but as well to what "engineering" itself is understood to be. Contemporary boundaries around what is and what is not engineering-or what is central to engineering versus what is peripheral-are neither inevitable nor immutable. Just as present-day engineering could have been different, so too can the future of engineering be different than what it is today. Efforts to steer changes will more likely be successful when informed by an appreciation for the contingentyet sticky-forces of engineering's history.

Our analysis works through the tension between these two points. On one hand, we hope to underscore the ways in which militarism and cultures of warfare have shaped engineering broadly and in contexts not limited to creating technologies of war. To this end, we offer a theoretical explanation of "warfare" beyond the common-sense of nation-states in conflict or politics by other means, using warfare as an analytic lens to investigate systematic power inequities more generally. Then, we look at two specific domains in which warfare practices are reproduced within engineering in the present: 1 ) in the structure of engineering labor and the related "command and control" approach to problem solving and 2) through an epistemology that (rhetorically at least) neatly separates out the "technical core" from the "social context" and then prioritizes the former 
over the latter in assessing competence. We conclude the paper with reflections on how the rubric of "social justice" in engineering might productively counterbalance the influence of militarism, resulting not only in different sorts of technologies but, perhaps more importantly, in different understandings of what, in fact, engineering is or might be.

The underlying motivation for this exercise is not merely academic, but to recast engineering in a way that aligns it better with social problem solving. Only by reimagining what engineering is, we argue, will engineers be able to systematically and robustly confront enduring social inequalities and the structures that maintain them. For warfare can be understood as more than bullets flying; it can be understood in broader terms as an expression of structural inequality, of unequal power relationships at multiple levels - the personal, the economic, the political, and the geopolitical. In human experience, our lives slide between these levels at any (and perhaps every) moment. Connecting experiences across these levels provides an opportunity, even demands, understanding engineering in a new way.

\section{Theoretical Foundations: Warfare, Discipline, AND Social PoWer}

Many critics striving for social justice in the modern world have tried to uncover the persistent foundations of social inequality. Politicians predictably stress consensus among their national populations-George W. Bush, early in his presidency, identified himself as a "uniter, not a divider" and Barack Obama's 2008 presidential campaign was founded on the literal reconciliation of national antagonisms in his own biracial heritage-but social critics have long sought to uncover social conflict rather than consensus. For some of these critics, including Antonio Gramsci and Michel Foucault, warfare has been a powerful heuristic device for revealing deep-seated structural inequalities that commonly go unnoticed. For them as with us, war is not simply a matter of armed conflict between (or sometimes within) nations, with definable partisans and a recognizable beginning, a middle, and a decisive end. Warfare, as an analytical lens, is a means of naming differences in power, in wealth, and in wellbeing, which persist between and within national frames. Warfare, in this sense, is a strident conceptualization of social conflict as well as the measures taken to ensure or combat its persistence.

In the early-20th century, Italian radical theorist Antonio Gramsci identified two modes of warfare in modern life. In his prison notebooks-he was a political prisoner of Benito Mussolini-Gramsci identified a difference between what he called a "war of maneuver" and a "war of position" (1971 [1929-1932]). Wars of maneuver are akin to battles between armies that are easily recognizable as opposing forces-regiments move and combat each other, resulting in a final decisive victory, where territory is gained or lost, governments are toppled or strengthened. War is understood in this sense as an anomaly, different from ordinary and peaceable states of affairs. But Gramsci understood "wars of position" differently, and this is one of his cardinal intellectual contributions. Wars of positions are those battles in which no force makes great headway; forces neither gain recognizable territory nor destroy their enemies. Wars of position are protracted struggles, which depend on the whole social apparatus of civil society-including its productive capacity-for their generative force.

"Wars of position" (as a concept) reflects Gramsci's basic belief in the importance of "culture" and civil society in social struggle, looking beyond nakedly visible military might. Wars of position are both subtler and arguably more durable than wars of maneuver. It was from his theory of society as engaged in a war of position that Gramsci developed the concept of "hegemony." For Gramsci, hegemony is an ongoing tension between opposing social forces-at times stable, at other times in crisis, depending on the particular constellation of forces as well as the specific historical conditions 
at a given moment. Different combinations of economic, political, social, and cultural change could prompt crisis in hegemony, and thus those in power are required to constantly struggle to maintain their position, just as those "on bottom" struggle to better their own lives. In Gramsci's hands, culture-broadly defined, but existing somewhere beyond the economy and the state, and which included educational practices - itself was a site of political, economic, and social struggle.

Following in the wake of Gramsci's work, philosopher Michel Foucault became one of the most influential critics of the late-20th century. In Discipline and Punish (1979), Foucault argued that the creation and maintenance of certain ways of knowing the world are structured by the emergent power dynamics of modernity-driven by a burgeoning capitalism, the demise of monarchies and growth of liberal democracies and illiberal state formations, belief in individual subjectivities, and so forth. At the time of Foucault's writing, most scholars believed that modern institutions-and these include prisons and hospitals, insane asylums and universities, and factories and the military-were more democratic than older, autocratic and monarchal systems. But in contrast to celebratory histories of human progress and liberation, Foucault argued that the new disciplinary institutions hid new kinds of power within their modern forms. Each of those institutions relied on expert forms of knowledge-in turn, criminology, biomedicine, psychiatry, pedagogy, scientific management, and military professionalization-steeped in the new relations between themselves and their subjects. If Gramsci opened culture and civil society for analysis as a domain of warfare and struggle, Foucault investigated the realm of "discourse" - the mutually constituting, swarming complexes of thought, language, institution, and practice-as a terrain of power.

According to Foucault, each field of knowledge develops its own experts, and while there might be some overlap, they are increasingly understood as distinct. Thus economists would come to understand their own field as distinct from politics; historians would become professionally distant from biologists, and engineers from sociologists and philosophers. As Paul Gilroy (1993) argued, the differentiation of these fields allowed many of their practitioners to understand their own analyses as distinct from and perhaps even unrelated to other emergent knowledge formations. Foucault argued that the structures of these knowledge/power systems, and the institutions that legitimate them, share a great deal-especially in how they affect how people think about the world, and how they think about themselves. In fact, one of Foucault's more memorable analyses of disciplinary education drew directly from the military.

By the eighteenth century, the soldier has become something that can be made; out of formless clay, an inapt body, the machine required can be constructed; posture is gradually corrected; a calculated constraint runs slowly through each part of the body, mastering it, making it pliable, ready at all times, turning silently into the automatism of habit; in short, one has "got rid of the peasant" and given him the "air of the soldier." (Foucault in Cohen \& Ferman 1996, pp. 715-716)

This was the historical period, Foucault argues, of the making of "Man-the-Machine," a form of social engineering striving to reconstruct modern personhood, even as it remade modern state institutions, from the university to the military. Foucault's soldier stands, salutes, and raises his rifle in certain specifically prescribed manners, at the micro-level of "movements, gestures, attitudes, rapidity: an infinitesimal power over the active body" (Foucault in Cohen \& Ferman 1996, p. 716)training and rote repetition transformed the peasant into a citizen-soldier, who needed little or no thought in the act of firing a weapon or obeying the order to charge.

The crux of discipline, according to Foucault, is in the detail of that training. That soldier becomes an ideal (if idealized) disciplinary subject. Thus training and education produce "subjected and 
practiced bodies, 'docile' bodies" (Foucault in Cohen \& Ferman 1996, p. 717). For Foucault, this is not repressive; it is not a kind of simple domination. In fact, it is keenly efficient and highly productive. Such discipline "increases the forces of the body (in economic terms)" even while it diminishes the political will that might oppose the newly emergent states (Foucault in Cohen \& Ferman 1996, p. 717). But for all of the thought he lavished on the people who became modern students and soldiers, Foucault spent less time interpreting the position of the people, and especially the colonized peoples in Algeria or in Indochina, at whom French soldiers pointed their rifles. Here, again, we have the difference between war-torn and war-built societies, and their implication in our own ongoing colonial histories.

\section{ENGINEERING DISCIPLINE/DISCIPLINING ENGINEERS}

In a variety of ways, militarism and cultures of warfare have shaped engineering. Sometimes this shaping has been direct and deliberate, but often it has been indirect, in the sorts of ways highlighted by Gramsci and Foucault-by bounding the domain of engineering practice, by inflecting assumptions about how problem solving should proceed, and by structuring what sorts of knowledge are considered to be credible. In this section, we describe two ways engineering can be understood as "disciplined by warfare mentalities," first by looking at the structure of engineering labor and how it directs engineering problem solving and second by considering "engineering epistemologies"-what is understood to be known in engineering as well as how it fits with other domains of knowledge. Rather than laying out specific historical chains of influence or identifying remnants of past practices in the present, our goal is to highlight how engineering's responses to deep structuring forces (e.g. militarism and cultures of warfare) end up insinuating themselves over time into the very fabric of what is understood to be "engineering."

\section{Engineering Labor}

The structure of engineering labor and the autonomy of practicing engineers are two places to see close connections between militarism and generalized engineering practice. Whether employed by military organizations, non-military government agencies, or industry, most engineers work as employees in organizations with relatively unambiguous hierarchical authority structures. ${ }^{4}$

The engineer-as-employee model, what Johnson (1989)—appropriate to our context-calls "guns for hire," assumes organizational and market incentives will adequately guide engineering labor toward outcomes consonant with the public interest. As Johnson puts it, this view assumes "that the marketplace and government regulation will do a good job of filtering out projects that should not be undertaken. It assumes that anything that makes it through the filter is good for society" (1989, p. 108). According to this model, the proper role of the engineering employee is simply to provide (as instructed) one's trained expertise, deferring to the logic of organizational decision making in its application. Organizational decisions, in turn, are understood to be steered (appropriately) by rational economic and political logics.

In this approach, engineers plug into existing organizational logics rather than providing a distinct logic of their own. More important, they plug into chain-of-command decision making structures that direct and constrain the input provided by individual engineers and engineering generally. For the purposes of our analysis, chain-of-command decision making in organizations need not be understood as deriving completely or directly from militarism. Yet scholars of engineering have

\footnotetext{
42006 US National Science Foundation statistics provide a sense of how labor is distributed by sector for the combined science and engineering workforce: 47\% "for-profit" (e.g., industry), 17\% self employed, 17\% education, $13 \%$ government, and 7\% non-profit. See http://www.nsf.gov/statistics/seind10/c3/c3s2.htm\#s6.
} 
long pointed out the susceptibility of engineers to deferring to organizational power structures and their interests that might otherwise conflict with engineering as an quasi-independent domain of practice (Meiksins, 1986).

The conflict of interest between engineering as an independent domain of practice and engineering in the service of organizational employers has played out repeatedly around the question of professionalization. Does engineering best serve the public interest when engineers work merely as employees in organizations (directed as they are primarily by financial and/or political logics) or when engineers exercise professional autonomy? This question becomes most poignant, of course, when "engineering judgment," however defined, conflicts with dominant financial and political interests.

Resistance to the engineer-as-employee model of engineering labor has been shown through a range of historical efforts to enhance the professional standing of engineers. Meiksins (1986) shows how tensions between professional autonomy of engineers and organizational demands for subservience ultimately led, in the late-1910s and early-1920s, to the demise of the American Association of Engineers, which was for a brief time the largest engineering professional organization. Similarly, Edwin Layton's (1986) The Revolt of the Engineers documents professionalization efforts in the US over the first half of the $20^{\text {th }}$ century, especially those directed at elevating the role of "social responsibility" within engineering. While certainly not a principled critic of capitalism, Layton (1983) famously argued that engineers might serve in "loyal opposition" to corporate interests.

Layton was also clear in highlighting the barriers to professional reform efforts: "The problem [of engineering that diverges from the public interest] was built into the very structure of the engineering profession and of engineering work" (1986, p. ix). Even the professional societies were largely supportive of deference to organizational authority, due in part to their financial support from corporations. Drawing on Layton and David Noble, Brown et al. (2009) summarize this relationship:

American engineers always had divided loyalties between their employers and their professional colleagues and institutions. Less well known is that during the post1945 heyday of American manufacturing, the big U.S. corporations played major roles in sustaining and funding the activities of the engineering professional societies. ${ }^{5}$

Although there are clear differences in the degree of professional autonomy held by engineers across national contexts (see, e.g., Meiksins \& Smith 1996), most engineers readily adopt, in Robert Zussman's (1985) words, "a business ethos." While the financial motivators are slightly different in government agencies, the chains of command associated with corporate organizations and government/military organizations are similar, and engineers there similarly experience strictly limited professional autonomy (Meiksins 1986).

Confluent with hierarchical authority structures within large bureaucratic organizations is a "command and control" approach to problem solving. Derived from military planning, commandand-control problem solving entails highly centralized decision making informed by predictive analysis, where prediction is limited to domains of inquiry with more-or-less rigid causation. Many

${ }^{5}$ Quotation taken from on-line version of article available at:

http://etc.technologyandculture.net/2009/10/normativities-of-engineers/. 
internal and external commentators understand engineering as centralized, hierarchical, and (with some exceptions in design) rigid in process, with some observers interpreting those characteristics positively and others negatively. As with Foucault, we need not judge the characteristics to note their power in shaping (i.e., disciplining) individual and group imaginations of what engineering is.

That engineers fit so well in (and are employed abundantly by) large, highly structured organizations-think General Electric or General Motors, not to mention the major military contractors-suggests a reciprocal relationship between the training of engineers (or, in Foucault's terms, the disciplining of bodies and minds) and command-and-control problem solving. Again following Foucault, this arrangement extends the power of engineers, both individually and collectively, by structuring and constraining their roles, but, for the same reasons, simultaneously diminishes their political will. With its direct and indirect connections to cultures of warfare, command-and-control problem solving adds another layer of disciplining to engineering practice.

With some notable exceptions, engineering educational institutions typically assume responsibility for preparing engineers for careers requiring deference to organizational authority and commandand-control problem solving. In other words, they assume responsibility for the initial disciplining of engineering students and manifest educational cultures facilitating exactly that. David Noble (1977) argued that this orientation, built into engineering education programs over decades, is tied directly to military interests. Going back to the Defense Act of 1920, Noble states "the new military creed, which identified training for industry with military training, coincided nicely with the corporate need for an 'industrial army' of properly adjusted and assembled 'economic units'”' (1977, p. 226).

In important respects, the needs of industry have changed considerably since the 1920s, and engineering educators and policy makers struggle to increase flexibility in the structure, process, and outcome (e.g., students) of engineering programs. But reform efforts are numerous, while change is glacial; employment in large, bureaucratic organizations and command-and-control problem solving remain dominant assumptions and realities in the education and practice of engineering.

\section{Engineering Epistemologies}

While preparation for and practice within large, bureaucratic organizations disciplines engineers in how they work, the disciplining process actually goes further. It also penetrates into engineering epistemologies - the theories of knowledge in and of engineering. By directing attention to epistemology, we are interested not in abstract, philosophical reflections of what is known or ultimately knowable, but instead in ordinary, common-sense notions of what makes engineering knowledge unique and relevant to social problem solving.

As Gramsci (1971) argues, what is "common sense" is also a matter of social power, determined as it is by ways of understanding that are sanctioned and supported through hegemonic struggle. As noted above, engineers and others regularly draw boundaries around engineering knowledge; they identify some things as within the domain of engineering (e.g., statics, optimization techniques, characteristics of fluid flow) and other things as outside of engineering proper-either within complementary domains (e.g., science, economics) or within competing domains (e.g., politics, culture). ${ }^{6}$ Contradicting the idea that engineering knowledge itself is neutral (that is to say, without

${ }^{6}$ By "competing," we suggest not that these domains are necessarily contradictory to engineering, however defined, but that the underlying assumptions and criteria for assessing validity exist in tension with engineering knowledge as understood within this epistemology. This tension is nicely captured in the phrase, 
predispositions regarding its application), we point to the long and deep history of military influence to suggest engineering knowledge is highly congruent with (not to mention essential to) militarism and warfare. And this, we argue, is true regardless of the context of application of that knowledge.

One notable facet of engineering knowledge congruent with militarism and cultures of warfare is the ubiquitous distinction made between the "technical core" of engineering expertise and competency in all things "social," including that which is political. Science studies scholarship (see, e.g., Hackett et al., 2008) provides analytic grounds for rejecting the easy distinction between (socalled "neutral") technical knowledge and (inherently valued) "social" knowledge. This scholarship shows how even the most undisputed factual knowledge-as with all human knowledge-has social underpinnings, both by virtue of its being human knowledge and by virtue of the fact it is the outcome of human social activity. But our point is narrower, namely that reliance on the distinction between technical and social knowledge in engineering is almost exclusively strategic-used to elevate the statue of particular approaches and worldviews but having limited epistemological usefulness in engineers' (technical) problem-solving activities, which are always necessarily situated in social (organizational, political, economic) contexts.

The distinction between technical and social facets of engineering is conceptually muddy terrain (Rachel \& Woolgar 1995), but it has been concretized in common understandings of engineering at least since the post-WWII period of technoscientific optimism. Partly as a result of the "success" of the Manhattan Project ${ }^{7}$ - which was an organizational achievement as much as a scientific and technical one-engineering research became increasingly scientized in both educational institutions and industry. Relying on engineers as highly disciplined, narrowly technical analysts in massive bureaucratic organizations proved successful again with Sputnik and then the Apollo Program, further intensifying an approach to engineering that subsumed interpretation of complex contextual signals within more straightforward, hierarchical organizational authority structures (Lucena, 2005). In an important sense, bureaucratic political and organizational logics expunged engineering of accountability beyond the narrow technical core.

Despite routinely being required to be competent in interpreting social dynamics-for example, in the interplay of knowledge and power within the organizational contexts in which they workedengineers' rhetoric has seized upon the distinction between "core" engineering knowledge and all the rest. Moments of questioning this approach have arisen throughout engineering's history, including during the Progressive Era (e.g., the American Association of Engineers [Meiksins, 1986]) and during the late-1960s and early-1970s counter-cultural response to western technoscientific hubris, manifesting in redirected attention toward political process (e.g., the Committee for Social Responsibility in Engineering [Moore, 2007]) and economic and environmental justice (e.g., the appropriate technology movement [Willoughby, 1990]). According to engineering historian, Matt Wisnioski, "A confluence of circumstances in the late 1960s generated alternatives to accepted conceptions of technology-a moment of new possibility that momentarily appeared to alter what it would mean to be an engineer" (2009, p. 779). But the centrality of narrow technical competence in defining engineering skill retained its dominance. As Wisnioski poignantly summarizes the results of the 1960s experiments (borrowing the words of an educational reformer), "Liberal

\footnotetext{
"Speaking truth to power," where truth implies science or engineering knowledge and power political knowledge.

7 The Manhattan Project's "success," of course, is dependent on one's criteria for assessment. As Masco (2006) shows, the Manhattan Project was deeply implicated in a colonial imagination of primitivism and the literal destruction of colonized people and places.
} 
education has failed." The engineer is a technical decision maker; "engineering" knowledge is technical knowledge.

Remnants of progressive experiments in engineering remain in the present (Nieusma, 2004, 2011). In addition to pockets of resistance within some engineering education and professional communities, scholarly attention to engineering-as a domain of knowledge and practice-is on the rise, as evidenced by the recent formation of the International Network for Engineering Studies (and its journal Engineering Studies), as well as the formation of the Engineering, Social Justice, and Peace international network (and this journal). Analytic interest in alternative epistemologies for science and engineering has intensified, too, especially within the field of science and technology studies (STS). New (post-positivist) models of science offer insight into possible future trajectories of engineering, including a relaxing of the rigid rhetorical boundary between the technical core and social context. In parallel, in the context of contemporary engineering education, interest in engineering practice aimed at addressing enduring social problems is blossoming anew. ${ }^{8}$ Unfortunately, to date, these two streams have remained mostly unconnected (Nieusma and Tang, 2011), as systematic instruction in the "social" side of engineering remains marginal, ad hoc, or just plain absent for most engineering students.

The distillation of engineering to a technical core may serve the interests of hierarchical, bureaucratic organizations, but it unnecessarily and unhelpfully limits the scope of engineering in solving broad social problems. And it fails to accommodate the diversity of interests and potential contexts of engineering practice. Much remains to be done in terms of fleshing out and disseminating an alternative engineering epistemology that responds to engineering's historical intersections with militarism, accepting its pervasive influence on how engineers come to know the world but identifying strategies for moving forward that loosen those connections.

\section{SOCIAL JUSTICE AND THE UNDISCIPLINING OF ENGINEERING}

The rubric of "social justice" serves as one especially productive alternative to embedded militarism within engineering, and it does so in several ways. Most obviously, social justice maintains a critical edge missing in more generic "human centered" approaches to engineering (e.g., humanitarian engineering, engineering for change, grand-challenges engineering). This critical edge comes in part from the association of social justice with progressive social movements, critical theory, and moral philosophy. It tempers "technical" imperatives by directing attention to social power imbalances surrounding all technology decision making and the inequitable material outcomes that inevitably result. An emphasis on social justice in engineering keeps alive questions of social power imbalances in ways that "the public good" or "safety of the public" cannot (rooted as they are in majoritarian national politics and priorities).

As a foundational assumption of engineering-if every engineer were to be educated and practice in environments that questioned the implications to social justice of engineering decisions-the rubric of social justice could play a different sort of role. Because engineers have been habituated to see social context as apart from the core of their expertise-distinct from what it is that makes them engineers - thinking about social justice prompts reexamination of their central assumptions. Social justice as an analytic framework forces engineers to step outside of a warfare mentality (and its associated economic-interests logics), to be sure. But it does more. It forces stepping outside of hierarchical authority structures and the command-and-control problem solving methods

\footnotetext{
${ }^{8}$ See, e.g., the National Academy of Engineering's “Engineering Grand Challenges," available at: http://www.engineeringchallenges.org/.
} 
appropriate to those structures. In a way, a social justice framework has the potential to upset the disciplining achieved in engineering, not erasing it but shining light on it and inviting scrutiny.

Because social justice so strongly diverges from militarism as a dominant framing of engineering, it might be seen as ideological or (to readers who recognize the embedded ideology of the militaristic/market approaches) counter-ideological, setting up a conflict between one (right) approach and another opposing approach. We would rather draw attention to the expectation, which is especially strong in engineering, of finding "one right answer"-a single best solution to a given problem, determined through rigorous, ideally quantitative predictive analysis. An alternative approach-and one that the social justice framework points toward directly-is consensus building through robust democratic deliberation, a process that includes engineers, to be sure, but also members of the many groups impacted by engineering decisions. Ultimately, then, a social justice framework might open a discussion of what engineering is and ought to be-conceptually, methodologically, and in terms of professional practice.

\section{ACKNOWLEDGEMENTS}

This article was made possible by support from the Australian Learning and Teaching Council Grant, "Engineering Education for Social and Environmental Justice" (CG10-1519). We would like to thank Dr. Rita Armstrong and the journal's blind reviewers for helpful suggestions in response to a prior version of this paper.

\section{REFERENCES}

Adas, Michael. (2006). Dominance by Design: Technological Imperatives and America's Civilizing Mission. Cambridge: Harvard University Press.

Alvarez, Luis. (2008). The Power of the Zoot: Youth Culture and Resistance during World War II. Berkeley: University of California Press.

Appy, Christian G. (1993). Workingclass War: American Combat Soldiers and Vietnam. Chapel Hill: University of North Carolina Press.

Brown, John K., Downey, Gary Lee, and Paula Diogo, Maria. (2009). The normativities of engineers: Engineering education and history of technology. Technology and Culture 50(4): 737-752.

Chafe, William H. (2010). The Unfinished Journey: America Since World War II, $7^{\text {th }}$ ed. New York: Oxford University Press.

Cohen, Mitchell, and Ferman, Nicole. (Eds.). (1996). Princeton Readings in Political Thought: Essential Texts since Plato. Princeton: Princeton University Press.

Du Bois, W. E. B. (1919). "Returning Soldiers.” In David Levering Lewis, ed. (1995). The Portable Harlem Renaissance Reader. New York: Penguin Books.

Foucault, Michel. (1979). Discipline and Punish: The Birth of the Prison, translated by Alan Sheridan. New York: Vintage.

Gilroy, Paul. (1993). The Black Atlantic: Modernity and Double Consciousness. London: Verso.

Gramsci, Antonio. (1971). Selections from the Prison Notebooks [1929-1932]. Edited and translated by Quintin Hoare and Geoffrey Nowell Smith. New York: International Publishers.

Hackett, Edward J., Amsterdamska, Olga, Lynch, Michal, and Wajcman, Judy. (2008). The Handbook of Science and Technology Studies, $3^{\text {rd }}$ ed. Cambridge: MIT Press.

Johnson, Deborah G. (1989). The social/professional responsibility of engineers." Annals of the New York Academy of Sciences.

Layton, Edwin T. (1983). Engineering needs a loyal opposition." Business and Professional Ethics 2(3): 51-59.

Lipsitz, George. (1994). Rainbow at Midnight: Labor and Culture in the 1940s. Urbana: University of Illinois Press. 
Lucena, Juan. (2005). Defending the Nation: U.S. Policymaking to Create Scientists and Engineers from Sputnik to the "War Against Terrorism." Lanham, MD: University Press of America.

Masco, Joseph. (2006). Nuclear Borderlands: The Manhattan Project in Post-Cold War New Mexico. Princeton: Princeton University Press.

Meiksins, Peter. 1986. "Professionalism and Conflict: The Case of the American Association of Engineers." Journal of Social History 19(3): 203-221.

Meiksins, Peter, and Smith, Chris. (Eds.). (1996). Engineering Labour. London: Verso.

Moore, Kelly. (2007). Disrupting Science: Social Movements, American Scientists, and the Politics of the Military, 1945-1975. Princeton: Princeton University Press.

Myers, Steven Lee. August 21, 2000. “Going Backwards: Led by US, Arms Sales Surge Globally.” New York Times.

Nieusma, Dean. (2004). “Alternative Design Scholarship. Working Toward Appropriate Design.” Design Issues 20(3): 13-24

Nieusma, Dean. (2011). "Engineering, Social Justice, and Peace: Strategies for Pedagogical, Curricular, and Institutional Reform." American Society for Engineering Education Annual Conference Proceedings. Washington, D.C.: ASEE.

Nieusma, Dean, and Xiaofeng Tang. (2011). "Teaching the Unbalanced Equation: Technical Opportunities and Social Barriers in the NAE Grand Challenges and Beyond." American Society for Engineering Education Annual Conference Proceedings. Washington, D.C.: ASEE.

Noble, David. (1977). America by Design: Science, Technology, and the Rise of Corporate Capitalism. Oxford: Oxford University Press.

National Science Foundation. http://www.nsf.gov/statistics/seind10/c3/c3s2.htm - s6. Accessed 29 November 2010.

Rachel, Janet, and Woolgar, Steve. (1995). The discursive structure of the social-technical divide: The example of information systems development." Sociological Review 43(2): 251-273.

Roland, Alex. (1993). Technology and war: The historiographical revolution of the 1980s. Technology and Culture.

Stockholm International Peace Research Institute (SIPRI). (2011). “Top Arms Exporters List.” Available at: http://armstrade.sipri.org/armstrade/html/export toplist.php (accessed 22 January 2011).

Willoughby, Kelvin W. (1990). Technology Choice: A Critique of the Appropriate Technology Movement. Boulder: Westview Press.

Wisnioski, Matthew H. (2009). "Liberal education has failed": Reading like an engineer in 1960s America. Technology and Culture 50(4): 753-782.

Zussman, Robert. (1985). Mechanics of the Middle Class: Work and Politics among American Engineers. Berkeley: University of California Press. 